\title{
SCIENTIFIC SUBSTANTIATION FOR OPTIMIZATION OF CROP ROTATION STRUCTURE AND IRRIGATION REGIMES OF INGULETS IRRIGATION SYSTEM CONSIDERING THE HYDROMODULE OF WATER SUPPLY
}

Morozov O. V.

\section{INTRODUCTION}

The vast majority of irrigated systems of Ukraine were built for solving problems related to the organization of food security of southern region in all weather conditions. Their task was to create zones of guaranteed production of food and feed grains, vegetables and high-quality forages. The design of irrigation systems envisaged specific structure of acreage: grain crops $40-45 \%$, of which $55-60 \%$ of winter crops; forage crops - 35-40\%, of which perennial grasses $50-60 \%$ and in the remaining areas - vegetable, technical and other crops. Such a structure provided sustainable yield of all crops, irrigation water and technique were used evenly throughout the watering season, soil fertility stabilized and improved ${ }^{1}$.

In the conditions of market relations development and the need to produce competitive products, there is a need for agricultural producers in maximum saturation of irrigated crop rotation with technical, vegetable crops, as the most profitable in modern economic conditions in the south of Ukraine. That leads to a decrease in irrigated soil fertility and their productivity ${ }^{2}$.

In solving this problem at the present stage of development of irrigated agriculture the important role belongs to crop rotations. The latter, in conjunction with technological measures, increases productivity of arable land by $25-30 \%$ with the simultaneous preservation and increase of soil fertility. At high saturation of these intensive crops the role of crop rotation as a biological method of regulation of phytosanitary regime significantly increases ${ }^{3}$. Under such conditions, the problem of reproduction of fertility of irrigated lands and environmental protection acquires a special significance.

The relevance of the subject is justified by the necessity in new approaches to the exploitation of irrigation systems - concentration on

\footnotetext{
${ }^{1}$ Ромащенко М.I. Наукові засади розвитку зрошення земель в Україні. К.: Аграр. наука, 2012. $28 \mathrm{c}$.

${ }^{2}$ Малярчук М.П. Система обробітку грунту: Наук. вид. Наукові основи охорони та раціонального використання зрошувальних земель України. Київ: Аграрна наука, 2009. C. 299-312.

${ }^{3}$ Зубець М.В. Функціонування аграрної науки в сучасних умовах. Вісник аграрної науки. 2000. № 4. С. 6-12.
} 
irrigated lands of the most profitable and cost-effective crops. In the newly created agricultural enterprises with limited irrigation area there is a need in organization of shorter crop rotations, taking into account the hydro module of irrigation system. Selection of crops in such farms should be determined by material and technical capabilities and climatic conditions. According to climatic conditions, selection of the most adapted for the region crops and their ratio should be settled.

The existing chaotic use of irrigated land now led to a substantial decrease in soil fertility, their ecological and agromeliorative conditions, reduced their resistance to self-regulation. Under such conditions it is necessary to substantiate scientifically the ways of stabilization of soil processes, one of which can be optimization of irrigation rates, allocation and ratio of crops.

The purpose of the work is: Scientific substantiation of the calculation of the project hydro module (consumption of water per hectare of irrigated area) in comparison with actual (projected) carrying capacity of intereconomic canals of the Ingulets irrigation system, taking into account landbound areas of state irrigated lands (on the example of P-1 canal).

To achieve this goal, the following tasks have been solved:

1. Optimizing the structure of acreage in the area of the intereconomic canal P-1, taking into account its carrying capacity;

2. Scientific substantiation of the norms of water requirements of basic crops, taking into account humidification conditions of the year.

\section{Research Methodology}

Research method: calculative method with a complex of analytical studies.

Hydro module - specific water consumption per 1 ha of a crop rotation area. The hydro module of the canal P-1 of the Ingulets irrigation system is determined by the formula:

$$
\mathrm{g}_{\text {syst. }}=\mathrm{Q} / \mathrm{F}, \mathrm{L} / \mathrm{sec} \cdot \mathrm{ha} \text {, }
$$

$\mathrm{g}_{\text {syst. }}$ - ordinate of hydro module of the canal P-1, L/sec ha;

$\mathrm{Q}$ - project limit of water supply;

$\mathrm{F}$ - project area of the canal P-1, ha.

Water consumption (hydro module), necessary for irrigation of crops on one focal hectare of the canal P-1 of the Ingulets irrigation system, is determined by the formula:

$$
g=\alpha \mathrm{m} /(3.6 \mathrm{~T} \mathrm{t}), \mathrm{L} / \mathrm{sec} \text { ha, }
$$

where $\mathrm{g}$ - ordinate of hydro module, $\mathrm{L} / \mathrm{sec}$ ha;

$\alpha$ - share of the sown area of a crop rotation, which is occupied by the crop or the relative area, $\%$;

$\mathrm{m}$ - irrigation rate, $\mathrm{m}^{3} / \mathrm{ha}$; 
$\mathrm{T}$ - duration of irrigation per day, hours;

$\mathrm{t}$ - duration of watering the field, days.

The value of the hydro module is determined for each watering of all crops in the irrigated array. The definition is carried out in tabular form.

For irrigated array (where there is a large number of agricultural enterprises, farms, crop rotation plots, crops, etc.) the value of hydro module is determined by summing:

$$
\mathrm{g}_{\text {irrig. syst. }}=\alpha_{1} \times \mathrm{g}_{1}+\alpha_{2} \times \mathrm{g}_{2+\ldots}+\alpha_{\mathrm{i}} \times \mathrm{q}_{\mathrm{i}} .
$$

The structure of sown areas must be in agreement with the water supply of the system. In the presence of irrigation systems with a hydro module of $0.3 \mathrm{~L} / \mathrm{sec} / \mathrm{ha}$ irrigated lands could be saturated with water-resistant crops and crops with close irrigation regime to $40-45 \%$; with a hydro module of $0.4 \mathrm{~L} / \mathrm{sec} / \mathrm{ha}-60-70 \%$ and more than $0.5 \mathrm{~L} / \mathrm{sec} / \mathrm{ha}-60-75 \%$. The determination of the ratio of these crops is carried out by the transformed formula of the hydro module

$$
a=\frac{q \times 8640 \times T}{m},
$$

Where $a$ is the share of a crop or a group of crops with close irrigation regime, $\%$;

$\mathrm{Q}$ - hydro module of the section, L/sec/ha;

$\mathrm{T}$ - watering period, days;

$m$ - irrigation rate, $\mathrm{m}^{3} / \mathrm{ha}$.

The ratio of crops in crop rotation should also ensure even distribution of labor during the vegetative period.

\section{Calculation of the actual hydro module of the inter-economic canal P-1 of the Ingulets irrigation system considering land areas of state irrigation}

The structure of crops on the irrigated lands should contribute to full and uniform use of water during the growing season. At the same time, the largest need in water of all sowing area and individual crops should be fully supplied by the carrying capacity of the inter-economic canal P-1 of the Ingulets irrigation system, and promote rational functioning of irrigation system, prevent idling periods in its work.

Crops included in a crop rotation have different irrigation regime, and hence, an unequal distribution of irrigation water, different irrigation norms and rates. For example, winter wheat uses $40 \%$ of irrigation water in May, and the remnants in June and September. For 42 days of the watering season in spring and summer $1800 \mathrm{~m}^{3} /$ ha is used, i.e. $42.8 \mathrm{~m}^{3} /$ ha per day. Spring barley uses all the irrigation water during the month of May. For 31 days $1400 \mathrm{~m}^{3} / \mathrm{ha}$ of irrigation water was consumed, i.e. $-45.2 \mathrm{~m}^{3} /$ ha per day. 
In corn and soybean, irrigation period started at average in the second decade of June, that is, after its completion in winter wheat, and lasted about ${ }^{4}$ 54-64 and 75-81 days ${ }^{5,6}$.

During this time, about $54.7-64.8$ and $39.5-42.7 \mathrm{~m}^{3} / \mathrm{ha}$ of water per day was used. It should be noted that corn consumes irrigation water during the irrigation period more even than soybean. Thus, corn in June usese about $31 \%$ of irrigation water, in July $-43 \%$, and in August - 26\%, and soybean in June - $12 \%$, in July - 33\%, and in August - 55\%.

Since the crops, which are a part of the acreage in the area of an intereconomic canal P-1, have different irrigation regimes, this affects the formation of the actual hydro module of the Ingulets irrigation system (Table 1, 2, Fig. 1).

Analysis of the obtained values by the hydro module of the Ingulets irrigation system (dated 01.11.2018) under the actual acreage and irrigation regimes in the month of July was $0.42 \mathrm{~L} / \mathrm{sec} / \mathrm{ha}$. This indicates that July and June are critical months for the use of the inter-economic canal P-1 with $53.2 \%$ of saturation with grain corn. The project values of the hydro module of P-1 canal of the Ingulets irrigation system and their parcel stations cannot satisfy it (Fig. 1).

\section{Calculation of the project hydro module of the inter-economic canal P-1 of the Ingulets irrigation system considering the land areas of state irrigation.}

As a result of the study, the peculiarities of formation of the structure of acreage are scientifically substantiated, and the norms of water requirements (taking into account the moisture supply of the year) of main crops taking into account the carrying capacity of the inter-economic canal P-1 of the Ingulets irrigation system are determined.

On the irrigation systems with a hydro module of $0.36 \mathrm{~L} / \mathrm{sec} / \mathrm{ha}$ the most optimal in terms of total water consumption is a combination of waterresistant (soybean, corn) and more drought-resistant (winter barley and wheat) crops, with specific weight 50 by $50 \%$ (Tables 3-8, Fig. 2, 3, 4).

\footnotetext{
${ }^{4}$ Писаренко П.В., Суздаль О.С., Булигін Д.О., Морозов В.В. Вплив умов вологозабезпечення та густоти стояння рослин на урожайність нових сортів сої. Зрошуване землеробство. Збірник наукових пращьь. Херсон: Айлант, 2011. Вип. 56. С. 91-95.

${ }^{5}$ Писаренко П.В., Суздаль О.С., Булигін Д.О., Морозов В.В. Економічна ефективність вирощування середньостиглих сортів сої в умовах півдня України. Зрошуване землеробство. Збірник наукових праць. Херсон: Айлант, 2012. Вип. 57. С. 262-266.

${ }^{6}$ Малярчук М.П., Писаренко П.В., Котельников Д.І. Продуктивність кукурудзи на зрошуваних землях півдня України за різних способів основного обробітку та доз внесення азотних добрив. Зрошуване землеробство. Збірник наукових пращь. Херсон: Айлант, 2015. Вип. 63.164 с.
} 


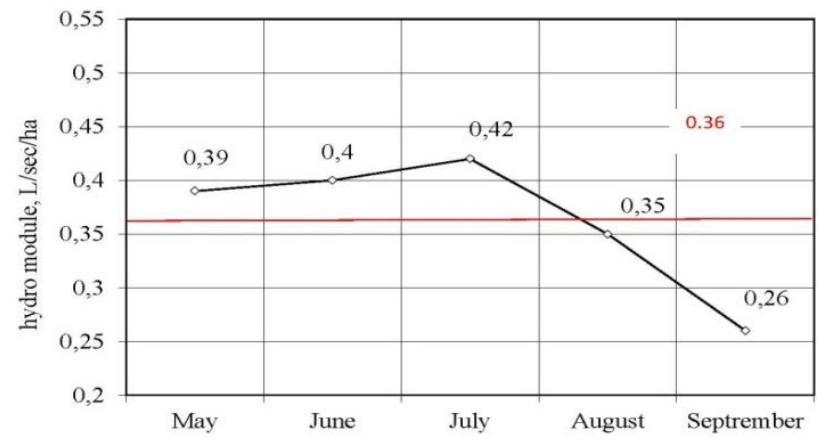

Fig. 1. The average ordinate of a hydro module of the inter-economic canal P-1 of the Ingulets irrigation system in case of actual norms and terms of irrigation, $\mathrm{L} / \mathrm{sec} / \mathrm{ha}$ (dated 01.11.2018)

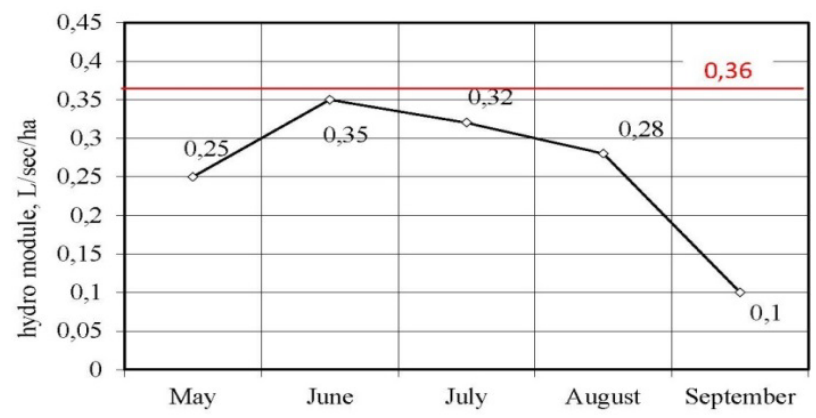

Fig. 2. The average ordinate of the hydro module of the inter-economic canal P-1 of the Ingulets irrigation system at the projected norms and terms of irrigation for dry years $(P=95 \%), \mathrm{L} / \mathrm{sec} / \mathrm{ha}$

Irrigation regime of crops regarding the norms of their water requirements should be calculated depending on:

- distribution of natural humidification coefficient;

- and by the water supply of the years (dry $(\mathrm{p}=95 \%)$, moderately dry $(\mathrm{p}=75 \%)$ and moderate $(\mathrm{p}=50 \%)$.

Such an approach to the use of irrigated lands will allow using the inter-economic canal P-1 of the Ingulets irrigation system in the project mode, stabilizing the melìorative conditions of the irrigated and neighboring lands, and, as a consequence, prevention of soil degradation, and increase in the efficiency of the irrigation system and the irrigated lands.

The increase of the share of corn and soybean over $50.0 \%$ leads to an increase in the specific water feed for irrigation, shortage of water resources and, consequently, the violation of scientific and reasonable irrigation regimes and decrease in the productivity of these crops. 
$\frac{\sqrt[0]{0}}{\sqrt{6}}$

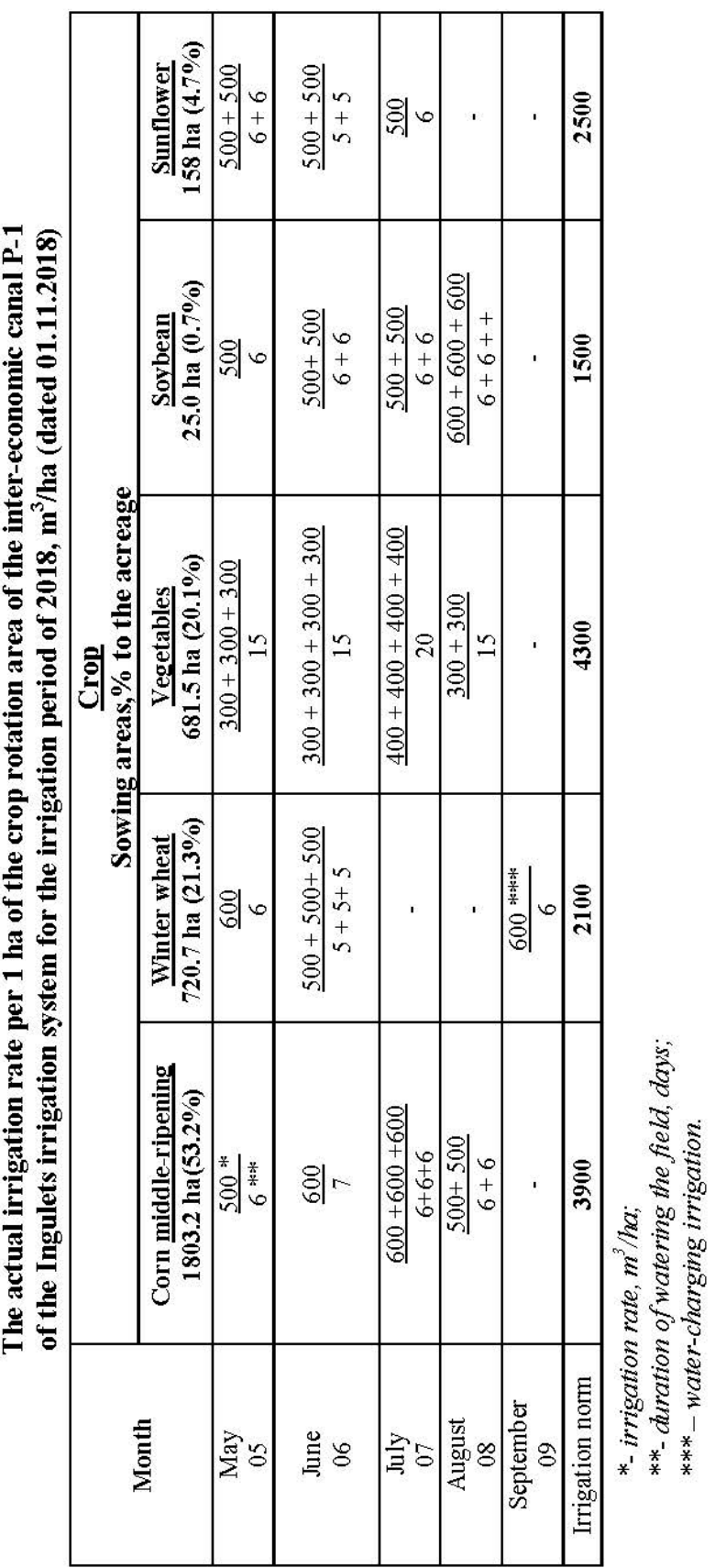


Table 2

The actual average hydro module of the inter-economic canal P-1 of the Ingulets irrigation system in 2018, L/sec/ha (dated 01.11.2018)

\begin{tabular}{|c|c|c|c|c|c|c|}
\hline \multirow[b]{2}{*}{ Month } & \multicolumn{5}{|c|}{$\begin{array}{c}\text { Crop } \\
\text { Sowing areas, } \% \text { to the acreage }\end{array}$} & \multirow[b]{2}{*}{$\begin{array}{c}\text { Average } \\
\text { ordinate } \\
\text { of the } \\
\text { hydro } \\
\text { module }\end{array}$} \\
\hline & $\begin{array}{c}\text { Corn } \\
\text { middle- } \\
\text { ripening } \\
\begin{array}{c}1803.2 \text { ha } \\
(53.2 \%)\end{array}\end{array}$ & $\begin{array}{l}\frac{\text { Winter }}{\text { wheat }} \\
\text { 720.7 ha } \\
(21.3 \%)\end{array}$ & $\begin{array}{c}\text { Vegetables } \\
\mathbf{6 8 1 . 5} \text { ha } \\
(53.2 \%)\end{array}$ & $\begin{array}{c}\frac{\text { Soybean }}{25.0 \text { ha }} \\
(0.7 \%)\end{array}$ & $\frac{\text { Sunflower }}{158 \text { ha }}$ & \\
\hline May 05 & 0.55 & 0.23 & 0.27 & 0.009 & - & 0.27 \\
\hline June 06 & 0.57 & 0.22 & 0.27 & 0.007 & 0.049 & 0.39 \\
\hline July 07 & 0.66 & - & 0.49 & 0.007 & 0.059 & 0.39 \\
\hline $\begin{array}{c}\text { Serstump } \\
08\end{array}$ & 0.55 & - & 0.27 & 0.009 & 0.049 & 0.31 \\
\hline $\begin{array}{l}\text { September } \\
09\end{array}$ & - & 0.26 & 0.27 & - & - & 0.21 \\
\hline
\end{tabular}

Table 3

The average project irrigation norm for dry $(P=95 \%)$ by the water supply years per 1 ha of the crop rotation area of the inter-economic canal P-1 of the Ingulets irrigation system for the irrigation period, $\mathrm{m}^{3} / \mathrm{ha}$

\begin{tabular}{|c|c|c|c|c|c|}
\hline \multirow[b]{3}{*}{ Month } & \multicolumn{5}{|c|}{$\begin{array}{c}\text { Crop } \\
\text { Sowing areas, } \% \text { to the acreage }\end{array}$} \\
\hline & \multicolumn{2}{|c|}{$\frac{\text { Corn }}{1694.2 \text { ha }(50 \%)}$} & \multirow[b]{2}{*}{$\begin{array}{l}\frac{\text { Winter }}{\text { wheat }} \\
779.3 \text { ha } \\
(23 \%)\end{array}$} & \multirow[b]{2}{*}{$\begin{array}{l}\begin{array}{c}\text { Barley } \\
\text { Winter }\end{array} \\
\text { (Spring) } \\
67.8 \mathrm{ha} \\
(2.0 \%)\end{array}$} & \multirow[b]{2}{*}{$\frac{\text { Vegetables }}{847.1 \text { ha }(25 \%)}$} \\
\hline & $\begin{array}{c}\text { Corn middle- } \\
\text { ripening } \\
847.1 \text { ha } \\
(25 \%)\end{array}$ & $\begin{array}{l}\text { Late- } \\
\text { ripening } \\
\text { corn } \\
847.1 \text { ha } \\
(25 \%)\end{array}$ & & & \\
\hline $\begin{array}{c}\text { May } \\
05\end{array}$ & $\frac{500^{*}}{6 * *}$ & - & $\frac{600+500}{6+6}$ & $\frac{500+500}{5+5}$ & $\frac{300+300+300}{10}$ \\
\hline $\begin{array}{c}\text { June } \\
06\end{array}$ & $\frac{500+500}{5+5}$ & $\frac{500+600}{5+6}$ & $\frac{500+500}{5+5}$ & $\frac{500}{5}$ & $\frac{300+300+300+300}{10}$ \\
\hline $\begin{array}{c}\text { July } \\
07\end{array}$ & $\frac{500+400+400}{5+5+5}$ & $\frac{600+600+600}{5+5+5}$ & - & - & $\frac{400+400+400+400}{12}$ \\
\hline $\begin{array}{c}\text { August } \\
08\end{array}$ & $\frac{500}{5}$ & $\frac{500+500}{5+5}$ & - & - & $\frac{300+300}{6}$ \\
\hline $\begin{array}{c}\text { September } \\
09\end{array}$ & - & - & $\frac{500 * * *}{5}$ & - & - \\
\hline $\begin{array}{c}\text { net water } \\
\text { requirements } \\
\text { norms for dry } \\
(\mathrm{P}=95 \%) \\
\text { by the water } \\
\text { supply years }\end{array}$ & 3300 & 3900 & 2100 & 1500 & 4300 \\
\hline
\end{tabular}

* - irrigation rate, $\mathrm{m}^{3} / \mathrm{ha}$;

** - duration of watering the field, days;

*** - water-charging irrigation. 


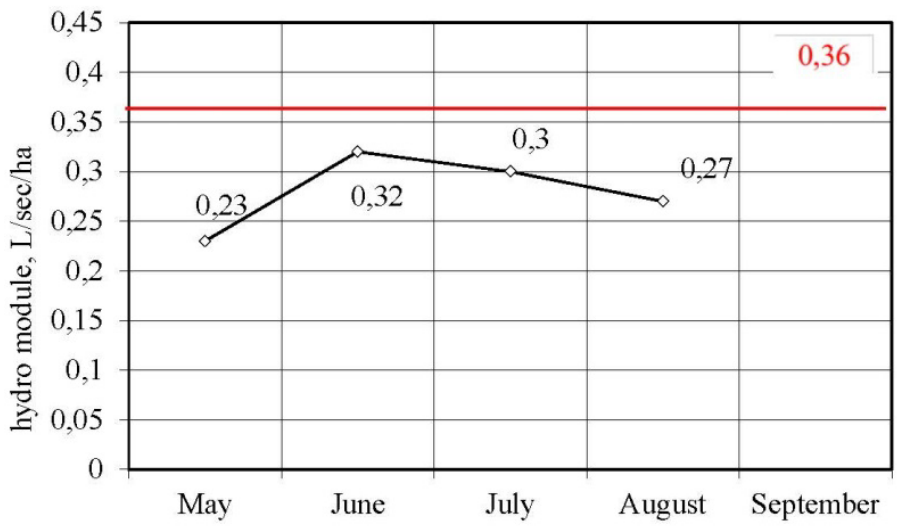

Fig. 3. The average ordinate of the hydro module of the inter-economic canal P-1 of the Ingulets irrigation system at the projected norms and terms of irrigation for moderately dry years $(P=75 \%), \mathrm{L} / \mathrm{sec} / \mathrm{ha}$

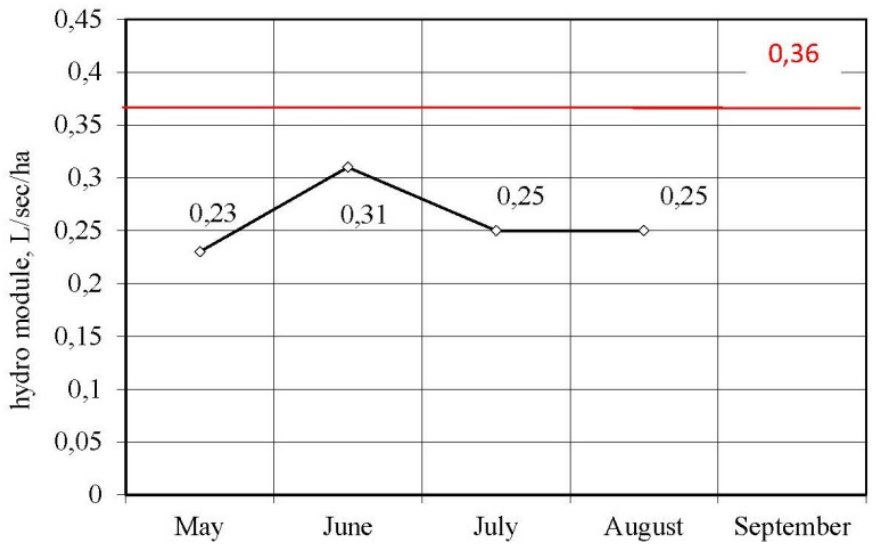

Fig. 4. The average ordinate of the hydro module of the inter-economic canal P-1 of the Ingulets irrigation system at the projected norms and irrigation terms for moderate years $(P=50 \%), \mathrm{L} / \mathrm{sec} / \mathrm{ha}$ 
Table 4

The average project irrigation norm for the moderately dry $(P=75 \%)$ by the water supply years per 1 ha of the crop rotation area of the inter-economic

canal P-1 of the Ingulets irrigation system for the irrigation period, $\mathrm{m}^{3} / \mathrm{ha}$

\begin{tabular}{|c|c|c|c|c|c|}
\hline \multirow[b]{3}{*}{ Month } & \multicolumn{5}{|c|}{$\begin{array}{c}\text { Crop } \\
\text { Sowing areas, } \% \text { to the acreage }\end{array}$} \\
\hline & \multicolumn{2}{|c|}{$\frac{\text { Corn }}{1694.2 \text { ha }(50 \%)}$} & \multirow[b]{2}{*}{$\begin{array}{c}\frac{\text { Winter }}{\text { wheat }} \\
779.3 \\
\text { ha } \\
(23 \%)\end{array}$} & \multirow[b]{2}{*}{$\begin{array}{c}\begin{array}{c}\text { Barley } \\
\text { Winter }\end{array} \\
\text { (Spring) } \\
67.8 \text { ha } \\
(2.0 \%)\end{array}$} & \multirow[b]{2}{*}{$\frac{\text { Vegetables }}{847.1 \text { ha }(25 \%)}$} \\
\hline & $\begin{array}{c}\begin{array}{c}\text { Corn } \\
\text { medium- }\end{array} \\
\underline{\text { ripe }} \\
847.1 \text { ha } \\
(25 \%)\end{array}$ & $\begin{array}{l}\text { Late- } \\
\text { ripening } \\
\text { corn } \\
847.1 \text { ha } \\
(25 \%)\end{array}$ & & & \\
\hline $\begin{array}{l}\text { May } \\
05\end{array}$ & $\frac{500 *}{6 * *}$ & - & $\frac{400+400}{5+5}$ & $\frac{400+400}{5+5}$ & $\frac{300+300+300}{9}$ \\
\hline $\begin{array}{c}\text { June } \\
06\end{array}$ & $\frac{400+400}{5+5}$ & $\frac{500+600}{5+5}$ & $\frac{500+400}{5+5}$ & $\frac{400}{5}$ & $\frac{300+300+300+300}{12}$ \\
\hline $\begin{array}{c}\text { July } \\
07\end{array}$ & $\frac{400+400+400}{5+5+5}$ & $\frac{500+500+500}{5+5+5}$ & - & - & $\frac{400+400+400+400}{12}$ \\
\hline $\begin{array}{c}\text { August } \\
08\end{array}$ & $\frac{500}{5}$ & $\frac{500+500}{5+5}$ & - & - & $\frac{300+300}{6}$ \\
\hline $\begin{array}{l}\text { September } \\
09\end{array}$ & - & - & $\frac{500^{* * *}}{5}$ & - & - \\
\hline $\begin{array}{c}\text { net water } \\
\text { requirements } \\
\text { norms for dry } \\
(\mathrm{P}=95 \%) \\
\text { by the water } \\
\text { supply years }\end{array}$ & 3000 & 3600 & 1700 & 1200 & 3900 \\
\hline
\end{tabular}

* - irrigation rate, $\mathrm{m}^{3} / \mathrm{ha}$;

** - duration of watering the field, days;

*** - water-charging irrigation.

Table 5

The average project irrigation norm for moderate $(P=50 \%)$ by the water supply years per 1 ha of the crop rotation area of the inter-economic canal P-1 of the Ingulets irrigation system for the irrigation period, $\mathrm{m}^{3} / \mathrm{ha}$

\begin{tabular}{|c|c|c|c|c|c|}
\hline \multirow{3}{*}{ Month } & \multicolumn{5}{|c|}{$\begin{array}{c}\text { Crop } \\
\text { Sowing areas, } \% \text { to the acreage }\end{array}$} \\
\hline & \multicolumn{2}{|c|}{$\begin{array}{c}\text { Corn } \\
16942 \text { ha }(50 \%)\end{array}$} & \multirow{2}{*}{$\begin{array}{l}\frac{\text { Winter }}{\text { wheat }} \\
779.3 \text { ha } \\
(23 \%)\end{array}$} & \multirow{2}{*}{$\begin{array}{c}\begin{array}{c}\text { Barley } \\
\text { Winter }\end{array} \\
\underline{\underline{\text { (Spring) }}} \\
67.8 \text { ha } \\
(2.0 \%)\end{array}$} & \multirow[b]{2}{*}{$\frac{\text { Vegetables }}{847.1 \text { ha }(25 \%)}$} \\
\hline & $\begin{array}{c}\text { Corn } \\
\text { medium-ripe } \\
847.1 \text { ha } \\
(25 \%)\end{array}$ & $\begin{array}{c}\text { Late-ripening } \\
\text { corn } \\
847.1 \text { ha } \\
(25 \%)\end{array}$ & & & \\
\hline $\begin{array}{c}\text { May } \\
05\end{array}$ & $\frac{400^{*}}{5 * *}$ & - & $\frac{500+500}{5+5}$ & $\frac{500+500}{5+5}$ & $\frac{300+300+200}{9}$ \\
\hline $\begin{array}{l}\text { June } \\
06\end{array}$ & $\frac{400+400}{5+5}$ & $\frac{500+600}{5+5}$ & $\frac{500}{5}$ & - & $\frac{300+300+300+200}{12}$ \\
\hline
\end{tabular}


Table 5 (continuance)

\begin{tabular}{|c|c|c|c|c|c|}
\hline $\begin{array}{c}\text { July } \\
07\end{array}$ & $\frac{400+400+400}{5+5+5}$ & $\frac{500+500+500}{5+5+5}$ & - & - & $\frac{300+300+300+200}{12}$ \\
\hline $\begin{array}{c}\text { August } \\
08\end{array}$ & $\frac{400}{5}$ & $\frac{500+400}{5+5}$ & - & - & $\frac{300+300}{6}$ \\
\hline $\begin{array}{c}\text { September } \\
09\end{array}$ & - & - & - & - & - \\
\hline $\begin{array}{c}\text { net water } \\
\text { requirements } \\
\text { norms for dry } \\
\left(\begin{array}{c}P=95 \%) \\
\text { by the water } \\
\text { supply years }\end{array}\right.\end{array}$ & $\mathbf{2 8 0 0}$ & $\mathbf{3 4 0 0}$ & $\mathbf{1 5 0 0}$ & $\mathbf{1 0 0 0}$ & $\mathbf{3 6 0 0}$ \\
\hline
\end{tabular}

$*_{-}$irrigation rate, $\mathrm{m}^{3} / \mathrm{ha}$;

** - duration of watering the field, days;

*** - water-charging irrigation.

Table 6

The average projected ordinate of the hydromodule of the P-1 canal at the optimization of acreage and scientifically based norms of water requirements for dry $(P=95 \%)$ by the water supply years, $L / s e c / h a$

\begin{tabular}{|c|c|c|c|c|c|c|}
\hline \multirow[b]{3}{*}{ Month } & \multicolumn{5}{|c|}{$\begin{array}{c}\text { Crop } \\
\text { Sowing areas, } \% \text { to the acreage }\end{array}$} & \multirow{3}{*}{$\begin{array}{c}\text { Average } \\
\text { ordinate } \\
\text { of the } \\
\text { hydro } \\
\text { module }\end{array}$} \\
\hline & \multicolumn{2}{|c|}{$\frac{\text { Corn }}{1694.2 \text { ha }(50 \%)}$} & \multirow[b]{2}{*}{$\begin{array}{c}\frac{\text { Winter }}{\text { wheat }} \\
\text { 779.3 ha } \\
(23 \%)\end{array}$} & \multirow[b]{2}{*}{$\begin{array}{c}\begin{array}{c}\text { Barley } \\
\text { Winter }\end{array} \\
\text { (Spring) } \\
67.8 \text { ha } \\
(2.0 \%)\end{array}$} & \multirow[b]{2}{*}{$\begin{array}{c}\text { Vegetables } \\
\mathbf{8 4 7 . 1 \text { ha }} \\
(25 \%)\end{array}$} & \\
\hline & $\begin{array}{c}\begin{array}{c}\text { Corn } \\
\text { middle- }\end{array} \\
\text { ripening } \\
847.1 \text { ha } \\
(25 \%)\end{array}$ & $\begin{array}{c}\text { Late- } \\
\text { ripening } \\
\text { corn } \\
847.1 \text { ha } \\
(25 \%)\end{array}$ & & & & \\
\hline $\begin{array}{c}\text { May } \\
05\end{array}$ & 0.26 & - & 0.27 & 0.03 & 0.42 & 0.25 \\
\hline $\begin{array}{c}\text { June } \\
06\end{array}$ & 0.31 & 0.32 & 0.29 & 0.025 & 0.55 & 0.35 \\
\hline $\begin{array}{c}\text { July } \\
07\end{array}$ & 0.27 & 0.38 & - & - & 0.61 & 0.32 \\
\hline $\begin{array}{c}\text { August } \\
08\end{array}$ & 0.32 & 0.32 & - & - & 0.46 & 0.28 \\
\hline $\begin{array}{l}\text { September } \\
09\end{array}$ & - & - & 0.34 & - & - & 0.10 \\
\hline
\end{tabular}

\section{CONCLUSIONS}

1. The structure of sown areas and crop rotations must be coordinated in accordance with the design and technical conditions of the Ingulets irrigation system and specialization of agricultural enterprises. At the same time, it is necessary to take into account its specialization, size of the land in use and water supply. 
The average projected ordinate of the hydro module of the P-1 canal at the optimization of acreage and scientifically based norms of water requirements for the moderately dry $(P=75 \%)$ by water supply years, L/sec/ha

\begin{tabular}{|c|c|c|c|c|c|c|}
\hline \multirow[b]{3}{*}{ Month } & \multicolumn{5}{|c|}{$\begin{array}{c}\text { Crop } \\
\text { Sowing areas, \% to the acreage }\end{array}$} & \multirow{3}{*}{$\begin{array}{c}\text { Average } \\
\text { ordinate } \\
\text { of the hydro } \\
\text { module }\end{array}$} \\
\hline & \multicolumn{2}{|c|}{1694.2 ha $(50 \%)$} & \multirow[b]{2}{*}{$\begin{array}{l}\frac{\text { Winter }}{\text { wheat }} \\
779.3 \text { ha } \\
(23 \%)\end{array}$} & \multirow[b]{2}{*}{$\begin{array}{c}\begin{array}{c}\text { Barley } \\
\text { Winter }\end{array} \\
\text { (Spring) } \\
67.8 \mathrm{ha} \\
(2.0 \%)\end{array}$} & \multirow[b]{2}{*}{$\begin{array}{c}\frac{\text { Vegetables }}{847.1 \text { ha }} \\
(25 \%)\end{array}$} & \\
\hline & $\begin{array}{c}\begin{array}{c}\text { Corn } \\
\text { middle- }\end{array} \\
\text { ripening } \\
847,1 \\
\text { ra25 } \\
\end{array}$ & $\begin{array}{c}\frac{\text { Late- }}{\text { ripening }} \\
\text { corn } \\
847,1 \text { ra25 }\end{array}$ & & & & \\
\hline $\begin{array}{c}\text { May } \\
05\end{array}$ & 0.26 & - & 0.23 & 0.02 & 0.46 & 0.23 \\
\hline $\begin{array}{c}\text { June } \\
06\end{array}$ & 0.25 & 0.34 & 0.26 & 0.02 & 0.46 & 0.32 \\
\hline $\begin{array}{c}\text { July } \\
07\end{array}$ & 0.25 & 0.32 & - & - & 0.62 & 0.30 \\
\hline $\begin{array}{c}\text { August } \\
08 \\
\end{array}$ & 0.31 & 0.32 & - & - & 0.46 & 0.27 \\
\hline $\begin{array}{c}\text { September } \\
09\end{array}$ & - & - & - & - & - & - \\
\hline
\end{tabular}

Table 8

The average projected ordinate of the hydro module of the P-1 canal at the optimization of acreage and scientifically based norms of water requirements for moderate $(P=\mathbf{5 0} \%)$ by the water supply years,

L/sec/ha

\begin{tabular}{|c|c|c|c|c|c|c|}
\hline \multirow[b]{3}{*}{ Month } & \multicolumn{5}{|c|}{$\begin{array}{c}\text { Crop } \\
\text { Sowing areas, \% to the acreage }\end{array}$} & \multirow{3}{*}{$\begin{array}{c}\text { Average } \\
\text { ordinate } \\
\text { of the } \\
\text { hydro } \\
\text { module }\end{array}$} \\
\hline & \multicolumn{2}{|c|}{$\begin{array}{l}\text { Corn } \\
1694.2 \text { ha }(50 \%)\end{array}$} & \multirow[b]{2}{*}{$\begin{array}{c}\frac{\text { Winter }}{\text { wheat }} \\
\frac{\text { 779.3 ha }}{(23 \%)}\end{array}$} & \multirow[b]{2}{*}{$\begin{array}{l}\text { Barley } \\
\text { Winter } \\
\text { (Spring) } \\
67.8 \mathrm{ha} \\
(2.0 \%)\end{array}$} & \multirow[b]{2}{*}{ 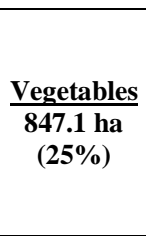 } & \\
\hline & $\begin{array}{c}\text { Corn } \\
\text { middle- } \\
\text { ripening } \\
847.1 \text { ha } \\
(25 \%)\end{array}$ & $\begin{array}{c}\text { Late- } \\
\text { ripening } \\
\text { corn } \\
847.1 \text { ha } \\
(25 \%)\end{array}$ & & & & \\
\hline $\begin{array}{l}\text { May } \\
05\end{array}$ & 0.25 & - & 0.29 & 0.025 & 0.41 & 0.23 \\
\hline $\begin{array}{l}\text { June } \\
06\end{array}$ & 0.25 & 0.32 & 0.29 & - & 0.42 & 0.31 \\
\hline $\begin{array}{c}\text { July } \\
07\end{array}$ & 0.26 & 0.32 & - & - & 0.42 & 0.25 \\
\hline $\begin{array}{l}\text { August } \\
08\end{array}$ & 0.26 & 0.28 & - & - & 0.46 & 0.25 \\
\hline $\begin{array}{c}\text { September } \\
09\end{array}$ & - & - & - & - & - & - \\
\hline
\end{tabular}


2. On the irrigation systems with a hydro module of $0.36 \mathrm{~L} / \mathrm{sec} / \mathrm{ha}$ the most optimal in terms of total water consumption is a combination of waterresistant (soybean, corn) and more drought-resistant (winter barley and wheat) crops, with a specific weight of 50 by $50 \%$.

3. Increasing the share of corn and soybean over $50.0 \%$ leads to an increase in the specific water feed for irrigation, water scarcity and, as a consequence, violation of scientific and reasonable irrigation regimes and decreases productivity of these crops.

\section{SUMMARY}

As a result of the study, the peculiarities of formation of the structure of acreage are scientifically substantiated, and the norms of water requirements (taking into account the moisture supply of the year) of main crops taking into account the carrying capacity of the inter-economic canal P-1 of the Ingulets irrigation system are determined.

On the irrigation systems with a hydro module of $0.36 \mathrm{~L} / \mathrm{sec} / \mathrm{ha}$ the most optimal in terms of total water consumption is a combination of waterresistant (soybean, corn) and more drought-resistant (winter barley and wheat) crops, with a specific weight of 50 by $50 \%$.

Increasing the share of corn and soybean over $50.0 \%$ leads to an increase in the specific water feed for irrigation, water scarcity and, as a consequence, violation of scientific and reasonable irrigation regimes and decreases productivity of these crops.

This approach to the use of irrigated land will allow using the intereconomic canal P-1 of the Ingulets irrigation system in the projected mode, stabilizing the meliorative conditions of the irrigated and adjacent lands, and, as a consequence, prevention of soil degradation, and an increase in the efficiency of the irrigation system and the irrigated lands.

\section{REFERENCES}

1. Ромащенко M.I. Наукові засади розвитку зрошення земель в Україні. К.: Аграр. наука, 2012. 28 с.

2. Малярчук М.П. Система обробітку грунту: Наук. вид. Наукові основи охорони та раціонального використання зрошувальних земель України. Київ: Аграрна наука, 2009. С. 299-312.

3. Зубець М.В. Функціонування аграрної науки в сучасних умовах. Вісник аграрної науки. 2000. № 4. С. 6-12.

4. Писаренко П.В., Суздаль О.С., Булигін Д.О., Морозов В.В. Вплив умов вологозабезпечення та густоти стояння рослин на урожайність нових сортів сої. Зрошуване землеробство. Збірник наукових праиь. Херсон: Айлант, 2011. Вип. 56. С. 91-95. 
5. Писаренко П.В., Суздаль О.С., Булигін Д.О., Морозов В.В. Економічна ефективність вирощування середньостиглих сортів сої в умовах півдня України. Зрошуване землеробство. Збірник наукових праиь. Херсон: Айлант, 2012. Вип. 57. С. 262-266.

6. Малярчук М.П., Писаренко П.В., Котельников Д.І. Продуктивність кукурудзи на зрошуваних землях півдня України за різних способів основного обробітку та доз внесення азотних добрив. Зрошуване землеробство. Збірник наукових праџь. Херсон: Айлант, 2015. Вип. $63.164 \mathrm{c.}$

Information about the author: Morozov O. V., Doctor of Agricultural Sciences, Professor, Chief Researcher of the Department of Irrigated Agriculture, Institute of Irrigated Agriculture of NAAS of Ukraine Kherson, Naddnipryanske, 73483, Ukraine 